\title{
A Dichotomy of Conflicting Duties
}

\author{
Jeff Montrose \\ Catholic University of Eichstätt-Ingolstadt
}

This is an electronic version of paper presented to the International Society for Military Ethics in Europe

(EuroISME) during its 4th annual conference, held May 25-28, 2014 in Koblenz, Germany and published by Brill Online Books and Journals. Available at http://booksandjournals.brillonline.com/content/books/9789004312135

“A Dichotomy of Conflicting Duties.” Didactics of Military Ethics: From Theory to Practice. Ed. Thomas R. Elssner and Reinhold Janke. Leiden: Brill, 2016. 158-72.

\begin{abstract}
This paper explores the dichotomy of a soldier's conflicting duties found in contemporary conflicts such as Iraq or Afghanistan. These two conflicting duties, the traditional duty of killdestroy and the mutually exhaustive duty of help-build, often collide at the tactical level in the complex environment of modern conflicts. When these two duties collide, it holds potential for tragic consequences that go beyond the tactical level where they occur and can have strategic impact.
\end{abstract}

Key Words: moral conflicts, strategic corporal, CNN effect, combat stress reaction

Soldiers in combat rarely hold such ascendancy of reason and ethical steadfastness against reflex when under attack

$$
\text { - Theodore Nadelson }{ }^{1}
$$

\section{Introduction}

Over the last two decades as the clearly defined parameters of the Cold War have faded into history an array of new security threats have materialized. Among them is the increase in non-state actors' ability to wage conflicts, failed states, international terrorism, and transnational threats, just to name a few. Moreover, globalization, despite its many positive aspects such as increased global connectivity and technological advances, has also inflamed many old conflicts and accelerated new ones through negative aspects such as increasing social and economic

\footnotetext{
${ }^{1}$ Nadelson, Theodore, Trained to Kill: Soldiers at War (1st, Johns Hopkins University Press, Baltimore 2005$) 42$.
} 
disparities $^{2}$. Transnational threats along with the ever increasing phenomena of globalization have created an array of complex national security challenges.

For the military this complex security environment and its new security threats represent significant challenges. The nature of warfare and threats to international security are changing; this is quite obvious to even the most casual observer. What is not so obvious is how state actors should deal with new threats and the role military force plays in dealing with them. Applying military force in response to new security threats is not necessarily achieving the desired goals it once $\mathrm{did}^{3}$. For the soldier this means that the range of task required to deal with these changing security threats is much broader and complex than that of previous generations ${ }^{4}$.

The purpose of this paper is to describe the current dichotomy of a soldier's conflicting duties observed in contemporary conflicts. I will first explore how on the one hand the changing nature of warfare presents soldiers with a rather broad range of non-combat situations in which soldiers are required to execute tasks not traditionally associated with military operations. On the other hand soldiers are still required to execute traditional tasks, i.e. kill enemy combatants. To show this I explain how the traditional tasks of a combat soldier, which I define as kill-destroy, has expanded into a second sphere of duties which I call help-build. Next, I show how modern conflicts often create conditions under which these two mutually exhaustive duties collide and create situations that are at best extremely delicate and mentally taxing and at worst hold the potential for strategic fallout.

\section{Conflicting duties}

Throughout the following pages I use the term soldier to mean those specific combat arms soldiers who are given the task of directly and repeatedly engaging an enemy force. In contemporary conflicts non-combat arms soldiers are quite often exposed to enemy contact, and combat is by no means unique to the infantry. Nonetheless, the primary task of non-combat arms soldiers is not to engage an enemy force directly. That is, they are not tasked to seek out the enemy and destroy them directly. Such tasks fall to combat arms soldiers, specifically the infantry and soldier. It can be argued that the infantry traditionally bears the brunt of warfare and subsequently will be exposed more often to the dichotomy of conflicting duties I describe in the following pages than soldiers in support roles. Thus, the term soldier throughout this paper refers to combat arms soldiers, but the situation which I described is not wholly unique to the infantry.

\footnotetext{
${ }^{2}$ Swain, Ashok, Understanding Emerging Security Challenges: Threats and Opportunities (1st, Routledge, Milton park 2013$) 2$. ${ }^{3}$ Gießmann, Hans J., 'Whither World Order? Challenges for Peace Studies' in Gießmann, Hans J., Kuźniar, Roman, and Lachowski, Zdzislaw (eds), International Security in a Time of Change: Threats - Concepts - Institutions (1st, Nomos, Baden-Baden 2004).

${ }^{4}$ Krulak, Charles C, 'The Strategic Corporal: Leadership in the Three Block War' (1999) 281 Marines Magazine 28-34.
} 


\section{Kill-Destroy}

The central task of a soldier has always been relatively straightforward. Whether one speaks of an ancient Assyrian soldier, a Greek Hoplite, a Japanese Samurai or an Army Ranger their primary task hasn't changed much in roughly 5000 years: to locate an enemy force and capture or kill it. The US Army's current tactical doctrine manual for infantry platoons and squads defines the task of the infantry as 'to close with the enemy, by means of fire and manoeuvre, in order to destroy or capture him, or to repel his assault by fire, close combat, and counterattack ${ }^{5}$. As the manual clearly states, 'the infantry's primary role is combat.'

In his book Black Hawk Down depicting the events of the 1993 Battle of Mogadishu, Mark Bowden sums up rather bluntly the primary role of the combat soldiers.

Soldiering was about fighting. It was about killing people before they killed you. It was about having your way by force and guile in a dangerous world, taking a shit in the woods, living in dirty, difficult conditions, enduring hardships and risks that could - and sometimes did - kill you. It was ugly work.... and if things went to hell and you had to slug it out, then it was time to summon a dark relish for mayhem. Why be a soldier if you couldn't exult in a heart-pounding, balls-out gunfight?

Therein rests the absolute central task of a soldier: to kill and destroy an enemy force. I label this primary and traditional role of a soldier simply as the kill-destroy role.

\section{Help-Build}

However, international security parameters have for various reasons changed over the last several decades and a consequence of these changes is that the role a soldier plays in the employment of military force has become significantly more complex. A new set of skills, apart from kill-destroy, are often demanded of soldiers to deal with these changes. Operations such as peacekeeping do not require soldiers to purposefully seek out an enemy force and engage them. Instead, such tasks revolve around 'monitoring cease-fires, separating hostile forces and maintaining buffer zones"7. Likewise, in humanitarian assistance or relief operations soldiers are 'increasingly involved in launching civilian-military projects, such as the building of bridges and schools or the distribution of aid $^{\prime 8}$. This new range of tasks which require a set of skills and

\footnotetext{
${ }^{5}$ Field Manual 3-12.8 Infantry Rifle Platoon and Squad (1st, Department of the Army, Washington, DC, 28 March 2007) 1-1.

${ }^{6}$ Mark Bowden, Black Hawk Down: A Story of Modern War (1st, Atlantic Monthly Press , New York: 1999) 24.

7 ‘50 Years of United Nations Peacekeeping Operations' (United Nations Department of Public Information 1998)

<http://www.un.org/en/peacekeeping/sites/50years/2.htm> accessed 15 May 2014.

8 'Humanitarian Work is the Task of Aid Workers,' (Global Policy Forum 2006)

<http://www.globalpolicy.org/component/content/article/176/31302.html> accessed 15 May 2014.
} 
knowledge which are distinct from the traditional skills demanded by the kill-destroy role, stands in opposition to kill-destroy and I label them simply help-build.

\section{Military Operations Other Than War}

The emergence of the new help-build role and the opposition it represents to kill-destroy did not, prior to the conflicts in Iraq and Afghanistan, present soldiers with a direct conflict between the two roles. Specifically, the operations which required soldiers to execute kill-destroy were almost always separated by time and space from missions that required help-build. To illustrate this I turn to a fictive Sergeant in the US Army who I will simply call Sergeant Smith?

As a typical infantry soldier who enlisted into the US Army in the late 1980's Sergeant Smith could have easily participated in all three types of operations: combat, peacekeeping and humanitarian during his carrier. One of Sergeant Smith's first deployments could have been the 1989 US invasion of Panama and again perhaps the 1991 Gulf War. Although the duration of both Panama and the Gulf War operations were limited in comparison to the conflicts in Iraq or Afghanistan, Sergeant Smith would have still been exposed to the intensity and confusion of combat. A few years later Sergeant Smith could have deployed to Somalia or Haiti as part of an international humanitarian operation. After returning from Haiti Sergeant Smith would have then most likely served the first of several deployments to the Balkans, specifically BosniaHerzegovina and Kosovo, or even to the Sinai to participate in an international peacekeeping operation.

From the end of the Cold War until the post 9-11 conflicts in Iraq and Afghanistan, these three types of missions: combat, humanitarian, and peacekeeping, were separated through time and space. That is, apart from a very few instances the spectrum of tactical challenges presented by peacekeeping and humanitarian type missions did not involve actual combat. The so called Battle of Mogadishu in Somalia is a clear example where significant combat action was encountered by US forces during a humanitarian mission. However, the majority of the US soldiers engaged in the Mogadishu fire fight were from Ranger and Special Forces units, which were deployed to Somalia not to help-build, but to kill-destroy. No doubt many other peacekeeping operations involved the risk of combat like situations, but the risk was quasipassive in nature. That is to say, for Sergeant Smith as a member of the US military, he was rarely the target of belligerents. The danger to the peacekeeping force came from being caught between and separating the warring parties and factions.

\footnotetext{
${ }^{9}$ I use the US military as an example due to my familiarity with that institution, but the concepts pertaining to this paper are by no means limited to soldiers in the US military.
} 
The US military subsequently drew a very clear line between the skills a soldier needed for combat (kill-destroy), and skills needed for operations which did not involve combat (help-build). These other non-combat missions were shoehorned into a single category known as Military Operations Other Than War (MOOTW $)^{10}$. The U.S. Army defined some of these MOOTW as search and rescue, peacekeeping, humanitarian assistance and disaster relief, and counterdrug operations. The manual does explain that the nature of such operations can transition into hostilities, but little if any emphasis in the manual is given to kill-destroy tasks.

Despite the increased operational tempo throughout the 1990's with non-combat deployments to, among others, Somalia, Haiti, Bosnia-Herzegovina, Macedonia and Kosovo, for Sergeant Smith the majority of his training would have still been focused on the traditional role of kill-destroy. The reason being that non-combat operations and training took a back seat to the traditional tasks of kill-destroy.

US Commanders must remember that their primary mission should always be to, prepare for, fight, and win America's wars. This is the most rigorous task facing any military establishment and requires nothing less than first priority when training and equipping forces ${ }^{11}$.

Thus, MOOTW represented the majority of military deployments in the US military during the 1990's but was seen as a secondary or contingency mission for US forces. Because combat operations and MOOTW remained separated by time and space, soldiers were rarely confronted directly with these two opposing roles.

\section{The three block war and the strategic corporal}

In 1999 the former Commandant of the US Marine Corps, General Charles Kurlak, observed the dramatic increase of US military forces to non-combat deployments and predicted that the fundamental change in the nature of future conflicts would force adversaries to adapt to asymmetric means to compensate for the disparity in the overwhelming conventional superiority of the US military power.

The lines separating the levels of war, and distinguishing combatant from 'non-combatant,' will blur, and adversaries, confounded by our 'conventional' superiority, will resort to asymmetrical means to redress the imbalance. Further complicating the situation will be the ubiquitous media

\footnotetext{
${ }^{10}$ Field Manual No. 100-7 DECISIVE FORCE: The Army In Theater Operations (1st, Department of the Army, Washington, DC, 31 May 1995) chapter 8.

11 Bonn, Keith E., Baker, Anthony, Guide to Military Operations Other Than War: Tactics, Techniques, \& Procedures for Stability \& Support Operations Domestic \& International: Tactics, Operations, Domestic and International (1st, Stackpole Books, Mechanicsburg 2000) 2.
} 
whose presence will mean that all future conflicts will be acted out before an international audience ${ }^{12}$.

In his article The Strategic Corporal: Leadership in the Three Block. War, Kurlak depicts a fictitious scenario in which a squad leader is confronted with all three types of missions within the space of three adjacent city blocks: combat operations, peacekeeping, and humanitarian relief; meaning each city block represents one of the three different types of situations. The central idea of his concept is that leaders of modern small-unit operations must be prepared and trained to operate simultaneously in all three situations.

There has been a blurring of these three missions; a convergence onto one single battle space, presumably as General Kurlak predicted, within a three block area of a city. Today Sergeant Smith will experience a much different environment in Afghanistan and most likely in any other future military operation involving ground forces than he would have in the 1990's. Moreover, the strategic success of such mission 'may hinge on decisions made by small unit leaders, and by actions taken at the lowest level ${ }^{13}$. The decisions Sergeant Smith makes on the battle field hold the potential for strategic success or failure and thus Kurlack coined the term strategic corporal.

The British General Rubert Smith made a similar observation that large scale war between state actors no longer exists, replaced by what he describes as war amongst the people. 'Civilians are the targets, objectives to be won, as much as an opposing force ${ }^{, 14}$. Not only are contemporary conflicts fought amongst the people and over the people, but due to real time media coverage, they are also literally fought in our homes. 'We fight in every living room in the world as well as on the streets and fields of a conflict zone ${ }^{15}$. Herein lies a significant factor in how Sergeant Smiths actions at the lowest tactical level can be rapidly amplified to the highest strategic level, namely through the CNN effect.

Named after the first international television news channel, Cable News Network, which broadcasts 24-hours a day in real time, the CNN effect is the phenomena that the media profoundly influences the foreign policy and diplomatic decision process of a state. Because world events are easily broadcast live as they occur, the time which heads of state and policy makers have to react to those events has been significantly reduced. Concerning military operations Steven Livingston wrote that media coverage has 'the potential to undermine public support for an operation and erode troop morale on the ground.' In the end, the actions of

\footnotetext{
${ }^{12}$ Krulak, Charles C, 'The Strategic Corporal: Leadership in the Three Block War' (1999) 281 Marines Magażine 2834.

13 Ibid.

${ }^{14}$ Smith, Rubert, The Utility of Force: The Art of War in the Modern World (1st, Vintage Books, New York 2005) 6.

15 Ibid 19.
} 
Sergeant Smith, particularly actions which result in the accidental or unintentional killing of noncombatants, hold the potential to undermine 'perceived American credibility and resolve in the world ${ }^{16}$.

Up until this point I have focused on the changing nature of warfare and the range of scenarios which often require modern soldiers to simultaneously execute both the traditional task of kill-destroy as well as the contemporary task of help-build in a single conflict zone. The situation for Sergeant Smith is exacerbated further by the CNN effect and it becomes even more difficult when we explore the issue deeper. Specifically, how Sergeant Smith's decisions are significantly influenced by his kill-destroy role in a scenario meant to help-build.

\section{An age old problem: the individual in battle}

Although training and indoctrination can transform even the most unruly civilian into a disciplined soldier no amount of training will ever turn a soldier into a simple instrument of warfare. As Michael Walzer so wisely remarked, the trigger is always a part of the gun it is never a part the $\operatorname{man}^{17}$. It is precisely this individuality of the soldier, his subjectivity, which sets the ultimate limits on the battlefield, not his machines.

The subjectivity of the soldier can be viewed as two sides of a $\operatorname{coin}^{18}$. On one side is an innovative resource to the waging of modern war. This is the individual's ability to adapt to complex and rapidly changing situations and find creative means to deal with those changes; independent of their position within the hierarchy of the military ${ }^{19}$. This is the core concept of the strategic corporal. Battlefield situations can change so rapidly that traditional means of reporting information to higher headquarters, despite advances in technology, will be too slow to issue new directives and orders. Junior leaders must be competent to act according to their commander's intent. They must also know that they have freedom to deviate from those initial orders when the situation no longer meets the condition from which they were issued.

However, the other side of the coin is a source of friction. The soldier's reaction to events in combat creates a weak point in waging war and the friction starts with the human psyche ${ }^{20}$. Continuous exposure to extreme situations and events in combat such as killing and imminent death amplify emotions, not the least among them; fear, doubt and anger. Neither external

\footnotetext{
${ }^{16}$ Livingston, Steven, Clarifying The CNN Effect: An Examination of Media Effects According to Type of Military Intervention Research Paper R-18 (1st, The Joan Shorenstein Center on the Press, Politics and Public Policy John F. Kennedy School of Government Harvard University, Cambridge 1997) 4.

${ }^{17}$ Walzer, Michael , Just and Unjust Wars: a moral argument with historical illustrations (2nd, Basic Books, New York 1992) 311.

18 Warburg, Jens , Militär und Seine Subjekte: zur Soziologie des Krieges (1st, Transcript Verlag, Bielefeld 2008).

${ }^{19}$ Keithly, David M. Ferris, Stephen P., 'Auftragstaktik, or Directive Control, in Joint and Combined Operations' (1999) Autumn, Parameters, 118-33.

${ }^{20}$ Warburg, Jens , Militär und Seine Subjekte: zur Soziologie des Krieges (1st, Transcript Verlag, Bielefeld 2008).
} 
influences such as training and counselling nor the soldier's self can completely prevent such extreme emotions from influencing their behaviour in combat.

In his widely published research of WWII infantry combat, S.L.A. Marshall discovered that only roughly 20 to 25 percent of US soldiers actually fired their weapons at enemy positions during battle. This was attributed to the human psyche's natural reluctance to kill other human beings; a rather straightforward example of the individual soldier creating a weak point in waging war. Marshall's study forced the U.S. military to adapt its training of soldiers, specifically rifleman, to overcome the individual's natural reluctance of killing. Pavlov like reflexive programming or conditioning desensitized recruits to the messy business of killing and by the end of the Korean War firing rate had increased to 55 percent, by Vietnam it was 90 percent $^{21}$. Today's modern technology enables a military to train its soldiers on a wide variety of combat simulations, ranging from live ranges to life-sized video simulations. In the heat of battle it is expected that soldiers fire their weapons accurately and effectively and in essence the US military has done a well in overcoming a soldier's natural reluctance of killing another human being.

Today Sergeant Smith's may be sufficiently desensitized to overcome his natural reluctance to kill, but the immediate issue at hand for Sergeant Smith is that the enemy he will encounter is hardly if ever easily identifiable. Added to this difficulty is that Sergeant Smith will be exposed to the extreme situations of combat for an extended period of time. The average deployment for Sergeant Smith to conflicts in Iraq and Afghanistan was 12 months with some deployments extended to 15 months ${ }^{22}$. Moreover, prolonged contact with such threats combined with physical strains such as pain, hunger and exhaustion will influence the emotions and behaviour of Sergeant Smith, often to the extreme. In his autobiography Goodbye to All That, Robert Graves a veteran of the First World War, remarked that after five months of fighting he had 'passed his prime.' Of his fellow officers he noted that at six months of combat an officer was 'still more or less all right.' At ten months he became a 'drag on the other company officers' and beyond one year 'he was worse than useless' ${ }^{23}$.

Kirson Weinberg's study of World War II combat veterans also found that after prolonged exposure to the extreme conditions of combat a soldier eventually becomes overwhelmed, and it is at this point that they are no longer able to 'formulate, enact, or complete a protective response.' A soldier may feel helpless and descend into a state of self-concern, focusing on

\footnotetext{
${ }^{21}$ Grossman, Dave, On Killing: The Psychological Cost of Learning to Kill in W ar and Society (1st, Back Bay Books., New York 1996) 35.

22 Tyson, Ann Scott and White, Josh, 'Strained Army Extends Tours To 15 Months' (Washington Post 12 April 2007) < http://www.washingtonpost.com/wp-dyn/content/article/2007/04/11/AR2007041100615.html> accessed 15 May 2014.

${ }^{23}$ Graves, Robert, Good bye to all that (Revised, Cassell \& Company Limited, London 1957) 152.
} 
measures of defence. His actions may become random and violent such as being 'trigger happy ${ }^{24}$. The Roman philosopher Seneca attributed such actions to anger or what we might today call battle rage. He described it as a sweeping force from which there is no turning back, remarking that 'deliberation or second thought are cut off' as a downward course is set in motion; driven to the bottom by its own weight ${ }^{25}$. The desensitization to killing and the act its self play a central role in the breakdown of a soldier's psyche, and because the soldier has been given a license to kill does little to protect him from his own fears and stress of combat ${ }^{26}$.

\section{The switch}

Memoirs and novels written by combat veterans are full of accounts of battle rage, and in its extreme cases it has commonly been excused as a brutal yet unavoidable reality of combat. Not least among these accounts is one from Guy Chapman's memoir where he tells the story of how a fellow officer recounts the storming of a German trench in World War I. After the unit advanced into the trench an unarmed German officer attempted to surrender to a British sergeant, who 'half mad with excitement' took the surrendering officer's field glasses and then shot the man in the head. Chapman concludes the story with words that somehow carry a very uncomfortable truth about combat. 'I don't suppose he ever thought what he was doing' Chapman writes. 'If you start a man killing, you can't turn him off like an engine... He was probably half out of his head ${ }^{27}$.

Roughly one hundred years later Sergeant Smith remains subject to the same exact human condition as that of the half-crazed British sergeant storming into a German trench. It is what I call the switch. It is the point where a soldier's ability to make moral and ethical judgments are influenced by emotional reactions to the point that the he is no longer capable of distinguishing right from wrong. Random and violent actions, the action of killing is 'switched' on and it cannot be easily 'switched' off. Battle rage, trigger happy, murder, call it what you will, the fact remains; Sergeant Smith is subject to the same physiological and emotional stress as soldiers in previous generations. However, several aspects make contemporary conflicts much more complex and stressful for Sergeant Smith.

As we saw earlier, Sergeant Smith has been sufficiently desensitized to overcome his natural reluctance to kill. On top of that his behaviour is influenced by extreme emotions brought on by the pressure of combat. Prolonged exposure to extreme situations, often up to 15 months added

\footnotetext{
${ }^{24}$ Weinberg, Kirson, 'The Combat Neuroses' (1946) 515 The American Journal of Sociology 472.

${ }^{25}$ Cooper, John, Procopé, J. F. , Seneca Moral and Political Essays (1st, Cambridge University Press, Cambridge, 2003) 25 .

${ }^{26}$ Jones, Edgar, 'The Psychology of Killing: The Combat Experience of British Soldiers during the First World War' (2006) 282 Journal of Contemporary History 236.

${ }^{27}$ Chapman, Guy, A passionate prodigality (New edition, Ashford,Buchan \& Enright, London 1985) 99-100.
} 
to multiple combat tours, amplify his emotions. The situation that makes this more sensitive for Sergeant Smith in say Iraq than it did for Guy Chapman in the trenches of the First World War, is that Sergeant Smith cannot readily and easily identify his enemy. To make matters worse, not only is the enemy unidentifiable, he is also indistinguishable from the civilian population as a whole. What's more, Sergeant Smith's two conflicting duties of kill-destroy and help-build have converged onto a single space. He is often required to help the civilian population within his duty of help-build, but at the same time he is told to kill-destroy certain groups within that population that he cannot readily identify.

\section{When good soldiers do bad}

Once Sergeant Smith reaches the point where the 'switch' is turned on, one needn't have much imagination or military experience to see the potential for disaster is immense. When it occurs, it will certainly be televised within days if not hours and will most likely hold some form of strategic consequence. However, one needn't turn to a fictive sergeant or address hypothetical situations as such events have already occurred in Iraq and Afghanistan.

So called checkpoint shootings such as the incident in Tal Afar, Iraq, where a family driving in a car failed to stop at a US checkpoint and soldiers opened fire. Both parents were killed in the shooting and their five children were injured ${ }^{28}$. Of course, such checkpoint shootings are by no means limited to the US military ${ }^{29}$, but they do represent a clear example of how the complex convergence of kill-destroy and help-build in a modern 'three-block' conflict can have deadly consequences. Such checkpoint shootings are rarely initiated by enemy contact though. Unclear and complex situations combined with stress can lead to situations where soldiers make deadly errors, such as shooting innocent passengers at a checkpoint late at night, but they are hardly attributed to battle rage. It is when soldiers are clearly acting within a kill-destroy frame that the potential for horrible events in a help-build situations are at their greatest. One such event did occur in November 2005 in Haditha, Iraq.

It was in the western province of $\mathrm{Al}$ Anbar in Haditha, Iraq, where the last vehicle in a patrol of US Marines was struck by an IED. The blast killed Lance Corporal Miguel Terrazas and

\footnotetext{
28 'Checkpoints test US troops' rules' (BBC News 8 March 2005)

<http://news.bbc.co.uk/2/hi/middle_east/4328579.stm> accessed e.g. 15 May 2014.

${ }^{29}$ One example involving German soldiers in Afghanistan. Gebauer, Matthias, 'Tod am Checkpoint: Bundeswehr entschädigt Familie des afghanischen Opfers‘ (Der Spiegel 23 July 2007)

<http://www.spiegel.de/politik/ausland/tod-am-checkpoint-bundeswehr-entschaedigt-familie-des-afghanischenopfers-a-637647.html> accessed 15 May 2014.
} 
seriously wounded two other marines ${ }^{30}$. Bing West wrote of the incident in The Road to Haditha and described the events after the IED blast as follows.

Streaming video from an Unmanned Aerial Vehicle circling overhead showed a confused situation, with marines at various locations manoeuvring amid radio chatter indicating incoming fire. The remaining ten men in Terrazas's squad approached a car that had stopped nearby. When the five men inside started to flee, the marines shot and killed them. The platoon leader later reported that his men took fire from a nearby house. They assaulted first one house, and then a second. When the battle was over, fourteen Iraqi men, four women, and six children had been killed ${ }^{31}$.

Most of the Marines involved in the killing had already served multiple deployments to Iraq, some were veterans of the fierce combat in Fallujah, and the conditions in Haditha were ripe for a disaster; armed men, who are trained to kill, exposed over an extended period of time to repeated enemy fire in an environment where the only characteristic to positively identify your enemy is 'military-aged males ${ }^{32}$ and a loved and likable comrade is killed by this unseen enemy. In an instant the 'switch' is turned on and it does not easily turn off. In such an environment one becomes overwhelmed and as Seneca wrote, a downward course is set in motion; driven to the bottom by its own weight.

Of those Iraqis killed in Haditha many were woken by the IED blast and subsequently shot while still wearing their pyjamas. The oldest Iraqi killed was 76 , confined to a wheelchair and shot nine times. His elderly wife was killed as well. The youngest killed on that day was 3. After the initial blast, which killed Lance Corporal Terrazas not a single casualty from the Marines was taken. A lone AK-47 was found and 'no one has claimed that the rifle had been fired" ${ }^{33}$. The incident serves as a very tragic example of the convergence of kill-destroy and help-build. Soldiers, in this case US Marines, were sent to an area to help rebuild a troubled region of Iraq. Under duress, fear, anger, and a deadly cocktail of indescribable emotions, those young men caught in the confusion of modern combat did what they were trained to do; kill and destroy, with tragic consequences.

\section{Conclusion}

\footnotetext{
30 McGirk, Tim, 'Collateral Damage or Civilian Massacre in Haditha?’ (Time 19 March 2006)

<http://content.time.com/time/world/article/0,8599,1174649,00.html> accessed 15 May 2014.

31 West, Bing, 'The Road to Haditha' (The Atlantic October 2006)

<http://www.theatlantic.com/magazine/archive/2006/10/the-road-to-haditha/305230/> accessed 15 May 2014.

32 Singer, Michael, 'The Killings in Haditha' (CBS 60 Minutes 15 March 2007)

<http://www.cbsnews.com/news/the-killings-in-haditha/3/> accessed 15 may 2014.

${ }^{33}$ Langewiesche, William, 'Rules of Engagement' (Vanity Fair November 2006)

<http://www.vanityfair.com/politics/features/2006/11/haditha200611> accessed 15 may 2014.
} 
The moral and legal questions surrounding the use of military force by liberal democracies is nothing less than a Pandora's Box and at the tip of this confusing and complex environment rests the conviction that the unintentional killing or wounding of non-combatants is unacceptable. The Vietnam Veteran Karl Marlantes rightly remarks in his book, What it's like to go to war, that the militaries of democracies must try to minimize the number of innocent victims in war $^{34}$.

Although unintentional killing and so called 'collateral damage' can be limited by technological advances in weaponry, precision weapons alone cannot prevent unintentional killing. It goes beyond the weapon to the soldier who uses it. Soldiers, specifically those soldiers who are required to interact with a local population and when necessary, engage an enemy force, need to know what contemporary combat is like and most importantly know how they are expected to act.

The importance of training cannot be avoided. Just as S.L.A. Marshall's work revealed in WWII that American Infantrymen were not acting as expected, in this instance not firing their weapons at enemy combatants, it was with subsequent psychological training that their behaviour was 'corrected'. Whether such psychological training does more damage to a soldier or not is debate for another paper, but two facts remain. Firstly, the situation in which soldiers were not acting as expected was identified. Secondly, their training was adjusted so that their behaviour matched expectations - firing rates subsequently increased after new training was introduced.

War for contemporary soldiers such as Sergeant Smith may often resemble the intensity of combat that Marlantes experienced in Vietnam or Marshall saw in WWII, but a deployment to a contemporary crisis zone for Sergeant Smith is also in many ways significantly more complex than from the days of Marshall or Marlantes. The training Sergeant Smith and his peers receive must reflect the type of environment they will find themselves in so that they act in ways that are acceptable for western democracies. The first step is to acknowledge the situation; namely, a dichotomy of ethical duties exists in the contemporary 'battle space' between kill-destroy and help-build.

The potential for tragic consequences when these two duties collide goes beyond the tactical level where they occur and can have strategic impact. Thus, in the future, militaries should recognize this conflicting dichotomy of ethical duties and prepare their soldiers for it.

\footnotetext{
${ }^{34}$ Marlantes, Karl. What it's like to go to war, quoted from the German version Was es heißt, in den Krieg qu ziehen (Arche Verlag, Zürich 2013) 313.
} 
Jeff Montrose holds a post graduate Master's degree in Peace and Security Studies from the Institute for Peace Research and Security Policy at the University of Hamburg, Germany as well as a BA in Political Science from the University of Georgia, Athens. A former U.S. Army officer, Jeff served as an infantry platoon leader in Iraq. He is currently a doctoral candidate at the Universität der Bundeswebr Munich and lecturers International Relations at the Catholic University of Eichstaett-Ingolstadt, Germany.

\section{Bibliography}

‘50 Years of United Nations Peacekeeping Operations' (United Nations 1998)

<http://www.un.org/en/peacekeeping/sites/50years/2.htm> accessed 15 May 2014

'Checkpoints test US troops' rules' (BBC News 8 March 2005)

<http://news.bbc.co.uk/2/hi/middle_east/4328579.stm> accessed e.g. 15 May 2014

'Humanitarian Work is the Task of Aid Workers,' (Global Policy Forum 2006)

<http://www.globalpolicy.org/component/content/article/176/31302.html> accessed 15 May 2014

Bonn, Keith E., Baker, Anthony, Guide to Military Operations Other Than War: Tactics, Techniques, \& Procedures for Stability \& Support Operations Domestic \& International: Tactics, Operations, Domestic and International (1st, Stackpole Books, Mechanicsburg 2000) 2

Chapman, Guy, A passionate prodigality (New edition, Ashford,Buchan \& Enright, London 1985) 288

Cooper, John, Procopé, J. F., Seneca Moral and Political Essays (1 st, Cambridge University Press, Cambridge, 2003)

Cooper, John, Procopé, J. F., Seneca Moral and Political Essays (1st, Cambridge University Press, Cambridge, 2003)

Field Manual 3-12.8 Infantry Rifle Platoon and Squad (1st, Department of the Army, Washington, DC, 28 March 2007)

Field Manual No. 100-7 DECISIVE FORCE: The Army in Theater Operations (1st, Department of the Army, Washington, DC, 31 May 1995)

Gebauer, Matthias, 'Tod am Checkpoint: Bundeswehr entschädigt Familie des afghanischen Opfers' (Der Spiegel 23 July 2007) < http://www.spiegel.de/politik/ausland/tod-amcheckpoint-bundeswehr-entschaedigt-familie-des-afghanischen-opfers-a-637647.html> accessed 15 May 2014 
Gießmann, Hans J., 'Whither World Order? Challenges for Peace Studies' in Gießmann, Hans J., Kuźniar, Roman, and Lachowski, Zdzislaw (eds), International Security in a Time of Change: Threats - Concepts - Institutions (1st, Nomos, Baden-Baden 2004)

Graves, Robert, Good bye to all that (Revised, Cassell \& Company Limited, London 1957) 368

Grossman, Dave, On Killing: The Psychological Cost of Learning to Kill in War and Society (1st, Back Bay Books., New York 1996)

Jones, Edgar, 'The Psychology of Killing: The Combat Experience of British Soldiers during the First World War' (2006) 282 Journal of Contemporary History 229 -246

Keithly, David M. Ferris, Stephen P., 'Auftragstaktik, or Directive Control, in Joint and Combined Operations' (1999) Autumn, Parameters, 118-33

Krulak, Charles C, 'The Strategic Corporal: Leadership in the Three Block War' (1999) 281 Marines Magazine 28-34

Langewiesche, William, 'Rules of Engagement' (Vanity Fair November 2006) <http://www.vanityfair.com/politics/features/2006/11/haditha200611> accessed 15 may 2014

Livingston, Steven, Clarifying The CNN Effect: An Examination of Media Effects According to Type of Military Intervention Research Paper R-18 (1st, The Joan Shorenstein Center on the Press, Politics and Public Policy John F. Kennedy School of Government Harvard University, Cambridge 1997)

Marlantes, Karl, Was es heißt, in den Krieg zu ziehen(Arche Verlag, Zürich 2013) 313

Marshall, SLA, Men Against Fire: The Problem of Battle Command (Reprint, Peter Smith, Gloucester 1978) 213

McGirk, Tim, 'Collateral Damage or Civilian Massacre in Haditha?’ (Time 19 March 2006) <http://content.time.com/time/world/article/0,8599,1174649,00.html> accessed 15 May 2014

Nadelson, Theodore, Trained to Kill: Soldiers at War (1st, Johns Hopkins University Press, Baltimore 2005) 208

Singer, Michael, 'The Killings in Haditha' (CBS 60 Minutes 15 March 2007) <http://www.cbsnews.com/news/the-killings-in-haditha/3/> accessed 15 may 2014

Smith, Rubert, The Utility of Force: The Art of War in the Modern World (1st, Vintage Books, New York 2005) 430

Swain, Ashok, Understanding Emerging Security Challenges: Threats and Opportunities (1st, Routledge, Milton park 2013) 184

Walzer, Michael , Just and Unjust Wars: a moral argument with historical illustrations (2nd, Basic Books, New York 1992) 361 
Warburg, Jens , Militär und Seine Subjekte: zur Soziologie des Krieges (1st, Transcript Verlag, Bielefeld 2008) 378

Weinberg, Kirson, 'The Combat Neuroses' (1946) 515 The American Journal of Sociology 465478

West, Bing, 'The Road to Haditha' (The Atlantic October 2006)

<http://www.theatlantic.com/magazine/archive/2006/10/the-road-to-haditha/305230/> accessed 15 May 2014 